\title{
Acetate induces anorexia via up-regulating the hypothalamic pro-opiomelanocortin (POMC) gene expression in rabbits
}

\author{
L. Liu, H. Liu, C. Fu, C. Li and F. Li ${ }^{1}$ \\ Shandong Agricultural University, \\ Shandong Provincial Key Laboratory of Animal Biotechnology and Disease Control and Prevention \\ 61 Daizong Street, Taian, Shandong 271018, P.R. China
}

KEY WORDS: acetate, anorexia, GPR43, JNK, POMC, hypothalamus, rabbits
Received: 22 October 2016

Revised: $\quad 6$ June 2017

Accepted: 9 August 2017
${ }^{1}$ Corresponding author: e-mail: chlf@sdau.edu.cn

\begin{abstract}
The aim of the study was to describe the effects of acetate on hypothalamic G-protein-coupled receptor (GPR) 41 or 43, 5'-AMP-activated protein kinase (AMPK) signalling, mitogen-activated protein kinases (MAPKs) signalling and (an)orexigenic neuropeptides. Forty rabbits (Hyla, 35-day old) were randomly assigned to one of two treatment groups: intravenous injection of acetate $\left(0.5 \mathrm{mg} \cdot \mathrm{kg}^{-1}\right.$ body weight) or vehicle (control). The acetate treatment decreased the rabbit feed intake within $5 \mathrm{~h}$ as compared with the control $(P<0.05)$. Although the acetate treatment had no effect on hypothalamic neuropeptide $Y$, agouti-related protein, cocaine-amphetamine-regulated transcript, GPR41, acetyl-CoA carboxylase, fatty acid synthase and carnitine palmitoyltransferase-1 mRNA levels $(P>0.05)$, it significantly increased the gene expression of the pro-opiomelanocortin $(P O M C)$ and GPR43 $(P<0.05)$. Moreover, intravenous injection of acetate did not affect the protein levels of phosphorylated extracellular signal-regulated kinases, AMPK or p38 MAPK in comparison with the control group $(P>0.05)$; however, there was a significant increase in GPR43 protein level and decrease in phosphorylated c-Jun N-terminal kinases (JNK) level $(P<0.05)$. So, acetate induced anorexia via the up-regulation of hypothalamic $P O M C$ gene expression, which may be associated with membrane GPR43 and intracellular JNK signalling.
\end{abstract}

\section{Introduction}

The hypothalamus plays a main role in the integration of nutritional status, along with the control of feeding and energy homeostasis. Several neuronal populations, particularly in the hypothalamic arcuate nucleus (ARC), are involved in the regulation of appetite. Among them are neuropeptide $\mathrm{Y}$ (NPY)/agouti-related protein (AgRP) and proopiomelanocortin (POMC)/cocaine-amphetamine- regulated transcript (CART) neurons, which are stimulated (NPY and AgRP) or suppressed (POMC and CART) by starvation (Brady et al., 1990; Mizuno et al., 1999; Savontaus et al., 2002). Central administration of NPY and AgRP increases food intake in mammals (Clark et al., 1984; Rossi et al., 1998), whereas CART and the melanocyte-stimulating hormone (an end product of POMC processing) decrease food intake when injected centrally (Tritos et al., 1998; Asakawa et al., 2001). 
AMP-activated protein kinase (AMPK) is a key indicator of the physiological energy status. The central injection of AICA-riboside (AMPK activator) initiates NPY neurons in the ARC to increase feed intake in rats (Kohno et al., 2011). In contrast, the central injection of compound C (AMPK inhibitor) induces anorexia in mice (Kim et al., 2004). In the hypothalamus, mitogen-activated protein kinases (MAPKs) are also notable signalling molecules needed for transduction of trophic signals. The MAPKs are serine/threonine-specific protein kinases that include the extracellular signal-regulated kinases ERK1/2, c-Jun N-terminal kinases (JNKs) and p38 MAPK (Cobb, 1999; Schaeffer and Weber, 1999). Fasting can activate ERK $1 / 2$ and p 38 MAPK signalling in the mouse hypothalamus (Morikawa et al., 2004). Inhibiting the hypothalamic ERK $1 / 2$ and p38 pathways prevent NPY synthesis and secretion (Kim et al., 2010). Additionally, Tsaousidou et al. (2014) demonstrated that the inhibition of JNK induces hyperphagia via the up-regulation of $A G R P$ gene expression.

Short-chain fatty acids (SCFAs) are released following dietary fibre fermentation in the gastrointestinal tract, in rabbits primarily in the caecum (Rabbani et al., 1999). Previous studies demonstrated that SCFAs contribute to homeostasis in energy balance via multiple cellular metabolic pathways and receptor-mediated mechanisms. For example, a high fibre diet can increase SCFAs production in the colon, leading to a higher SCFAs concentration in the portal system, which activates AMPK in the liver and prevents metabolic syndrome (Hu et al., 2010). SCFAs can increase the rate of lipolysis in 3T3-L1 adipocytes via activation of p38 MAPK signalling (Rumberger et al., 2014). In addition, SCFAs can increase energy expenditure, resulting in an improvement in glucose tolerance and in an increase of energy utilization via binding G-protein coupled receptors (GPR) 41 or GPR43 (also called free fatty acids receptors 3 and 2, respectively) (Kimura et al., 2014). SCFAs enhance the release of the anorectic hormones, peptide tyrosine-tyrosine 3-36 (PYY3-36) and glucagon-like peptide-1 (GLP1) from colonic L cells, as well as leptin from adipocytes (Chambers et al., 2015). The concentration of produced acetate is higher than of other SCFAs in rabbits, accounting for $75 \%$ of the total SCFAs in the caecum (Rabbani et al., 1999). So, acetate plays a direct role in the central regulation of appetite. According to Frost et al. (2014), in mice undergoing an acetate treatment a decrease and increase of the hypothalamic Agrp and Pomc gene expres- sions, respectively were noted. Although the role of SCFAs, especially acetate, on energy homeostasis in mammalian species has been extensively studied, the signalling pathway related to the acetate process regulating hypothalamic appetitive peptides in rabbits requires further evaluation. Rabbit can quickly absorb and metabolize acetate from gut, so the aim of the study was to investigate the effect of acute acetate treatment on hypothalamic GPR41/43, AMPK or MAPKs signalling in rabbits to determine the relationship between acetate and hypothalamic orexigenic or anorexigenic peptides. These findings would allow a better insight into the appetite regulation by acetate and indirectly reveal the role of dietary fibre in energy homeostasis.

\section{Material and methods}

\section{Animals}

Forty Hyla rabbits were individually housed in cages $(60 \times 40 \times 40 \mathrm{~cm})$ in a closed building (max. temp. $25{ }^{\circ} \mathrm{C}$, min. temp. $20{ }^{\circ} \mathrm{C}, 12 / 12$ light/dark cycle). The diets were formulated according to de Blas and Mateos (2010) and pelleted by pressure to $3.5 \mathrm{~mm}$. All rabbits received a starter diet containing $16 \%$ crude protein, $14 \%$ crude fibre and $11 \mathrm{MJ} \cdot \mathrm{kg}^{-1}$ of digestible energy and had continuous access to feed and water during the rearing period.

The study was approved by Shandong Agricultural University (Shandong, China) and was conducted in accordance with the 'Guidelines for Experimental Animals' of the Ministry of Science and Technology (Beijing, China).

\section{Experimental protocol and sample collection}

At 35 day of age, 40 rabbits of similar body weight (980 $\pm 40 \mathrm{~g})$ were randomly assigned to one of two groups (20 replicates per group, 1 rabbit per replicate) and subjected to one of two treatments: 1. intravenous injection of acetate $\left(0.5 \mathrm{~g} \cdot \mathrm{kg}^{-1}\right.$ body weight; acetate $)$ and 2 . sham-treatment $\left(1 \mathrm{ml} \cdot \mathrm{kg}^{-1}\right.$ body weight of saline; control). Feed intake was recorded 1, 2, 3, 4 and $5 \mathrm{~h}$ after injection. The experiment was repeated twice. During the second experiment, the rabbits were fasted for $4 \mathrm{~h}$ after acetate administration and sacrificed by exsanguination. The ARC was collected according to ManoOtagiri et al. (2006) and Prior et al. (2010). After snap-freezing in liquid nitrogen, the tissue samples were stored at $-70{ }^{\circ} \mathrm{C}$. 
Table 1. Gene-specific primers used for analysis of gene expression

\begin{tabular}{|c|c|c|c|}
\hline $\begin{array}{l}\text { Genes } \\
\text { (abbreviation, name and alternative abbreviation) }\end{array}$ & $\begin{array}{l}\text { GenBank access } \\
\text { No. }\end{array}$ & $\begin{array}{l}\text { Forward (F) and reversed (R) primer sequence } \\
\left(5^{\prime} \rightarrow 3^{\prime}\right)\end{array}$ & $\begin{array}{l}\text { Product size, } \\
\text { bp }\end{array}$ \\
\hline $\begin{array}{l}\text { GAPDH } \\
\quad \text { (glyceraldehyde 3-phosphate dehydrogenase) }\end{array}$ & NM_001082253 & $\begin{array}{l}\text { F: TGCCACCCACTCCTCTACCTTCG } \\
\text { R: CCGGTGGTTTGAGGGCTCTTACT }\end{array}$ & 163 \\
\hline $\begin{array}{l}\text { NPY } \\
\quad \text { (neuropeptide Y) }\end{array}$ & NM_001160286.1 & $\begin{array}{l}\text { F: CCTCATCACCAGGCAGAGAT } \\
\text { R: ATTTCGTTTCCCATCACCAC }\end{array}$ & 137 \\
\hline $\begin{array}{l}\text { AGRP } \\
\quad \text { (agouti-related protein) }\end{array}$ & XM_017342298.1 & $\begin{array}{l}\text { F: GCTACTGCCGCTTCTTCAAC } \\
\text { R: CCATTCTTTATTGGCGTTCC }\end{array}$ & 133 \\
\hline $\begin{array}{l}\text { POMC } \\
\text { (pro-opiomelanocortin) }\end{array}$ & XM_008254814 & $\begin{array}{l}\text { F: GCCTGGAAGATGCTGAGGT } \\
\text { R: CTCCTGACACTGGCTGCTCT }\end{array}$ & 102 \\
\hline $\begin{array}{l}\text { CART } \\
\quad \text { (cocaine-amphetamine-regulated transcript; CARTPT) }\end{array}$ & XM_008274526 & $\begin{array}{l}\text { F: AGGAGCCAGGATTGGGAAG } \\
\text { R: CTGATGGAAGAGCGTGGAAG }\end{array}$ & 101 \\
\hline $\begin{array}{l}\text { GPR41 } \\
\quad \text { (G-protein-coupled receptor 41; FFAR3) }\end{array}$ & XM_017338154.1 & $\begin{array}{l}\text { F: CCATCTATCTCACCTCCCTGTTC } \\
\text { R: AACCAGCAGAGCCCACTGAC }\end{array}$ & 130 \\
\hline $\begin{array}{l}\text { GPR43 } \\
\quad \text { (G-protein-coupled receptor 43; FFAR2) }\end{array}$ & XM_002722218 & $\begin{array}{l}\text { F: CGTCCAACTTCCGCTGGTA } \\
\text { R: CTTGTACTGCACGGGGTAGG }\end{array}$ & 146 \\
\hline $\begin{array}{l}\text { ACC } \\
\qquad \text { (acetyl-CoA carboxylase alpha; ACACA) }\end{array}$ & XM_002719077 & $\begin{array}{l}\text { F: GTGGTCTTCGTGTGAACTGG } \\
\text { R: TTCTTCTGCTGCCTTTAGCC }\end{array}$ & 122 \\
\hline $\begin{array}{l}\text { FAS } \\
\qquad \text { (fatty acid synthase; FASN) }\end{array}$ & KF201292 & $\begin{array}{l}\text { F: ACCACGTCCAAGGAGAGCA } \\
\text { R: AGTTCTGCACCGAGTTGAG }\end{array}$ & 112 \\
\hline $\begin{array}{l}\text { CPT1 } \\
\quad \text { (carnitine palmitoyltransferase 1) }\end{array}$ & XM_002724092 & $\begin{array}{l}\text { F: ATTCTCACCGCTTTGGGAGG } \\
\text { R: ACGGGGTTTTCTAGGAGCA }\end{array}$ & 196 \\
\hline
\end{tabular}

\section{RNA isolation and gene expression analysis}

Total RNA extraction and qRT-PCR were performed as described previously by Liu et al. (2014). Sequences of primers are presented in Table 1. The PCR data were analysed with the $2-\Delta \Delta C_{\mathrm{T}}$ method (Livak and Schmittgen, 2001). The mRNA levels of target genes were normalized to glyceraldehyde 3-phosphate dehydrogenase $(G A P D H)$ mRNA $\left(\triangle \mathrm{C}_{\mathrm{T}}\right)$. On the basis of the $\mathrm{C}_{\mathrm{T}}$ values, GAPDH mRNA expression was stable across the treatments $(P>0.1)$. The control group was deemed to be 1 .

\section{Protein preparation and western blotting}

The tissue samples were homogenized in radioimmunoprecipitation assay lysis buffer (Beyotime, Jiangsu, China) and the protein concentration was determined using a BCA assay kit (Beyotime, Jiangsu, China). After boiling samples with Laemmli buffer at $100{ }^{\circ} \mathrm{C}$ for $5 \mathrm{~min}$, the protein extracts (50 $\mu \mathrm{g}$ of protein) were subjected to electrophoresis in 7.5 to $10 \%$ SDS polyacrylamide gels at $20 \mathrm{~mA}$ for $3.5 \mathrm{~h}$. The separated proteins were then transferred to nitrocellulose membranes (Cat No. N9145, Millipore, Billerica, MA, USA) with use of wet transfer $\left(200 \mathrm{~mA}, 4{ }^{\circ} \mathrm{C}, 2 \mathrm{~h}\right)$. Electrophoresis and transfer were carried out with use of
Mini-PROTEAN ${ }^{\circledR}$ System (Bio-Rad Laboratories, Inc., Hercules, CA, USA). The membranes were blocked with 5\% defatted milk in Tris-buffered saline (TBS) for $50 \mathrm{~min}$ and therefore immunoblotted with the following primary antibodies: $\mathrm{p}$-AMPK $\alpha^{\text {Thr } 172}$

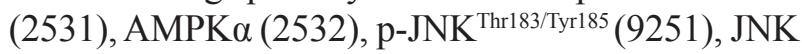

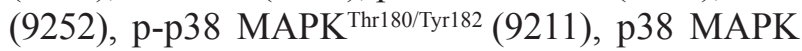
(9212), p-ERK1/2 ${ }^{\text {Thr202//yr204 }}$ (9101), ERK1/2 (9102) (1:1000, Cell Signaling Technology Inc., Beverly, MA, USA) and GPR43 (sc-28420) (1:1000, Santa Cruz Biotechnology, Santa Cruz, CA, USA). Protein detection was performed using the HRP-labelled IgG $(\mathrm{H}+\mathrm{L})(1: 1000$, Beyotime, Jiangsu, P.R. China) secondary antibody by enhanced chemiluminescence using BeyoECL Plus reagent (Beyotime, Jiangsu, China). Monoclonal mouse anti-GAPDH antibody (1:1000, Beyotime, Jiangsu, PR China) was used as a loading control. Protein transfer was confirmed by visualization of pre-stained molecular weight markers (Bio-Rad, Berkeley, CA, USA). Western blots were developed and quantified using a BioSpectrum 810 with VisionWorksLS 7.1 software (UVP LLC, Upland, CA, USA). After phosphorylated proteins quantification the membranes were stripped and the total amount of the same proteins was quantified following the same procedure starting with membrane blocking. 


\section{Adenosine-5' -triphosphate (ATP) content analysis}

The concentration of ATP in the hypothalamus tissue was estimated with the Waters 515 reversedphase high performance liquid chromatography system (Waters, Milford, MA, USA) using a modification of the approach described by Smolenski and Yacoub (1993). Separation was performed with a reversed-phase Diamonsil C18 column (Dikma, Beijing, China) that was equilibrated with methyl alcohol at room temperature. The injection volum was $10 \mathrm{ml}$, and flow was maintained at $1 \mathrm{ml} \cdot \mathrm{min}^{-1}$. Detection of ATP was achieved at $254 \mathrm{~nm}$ with the Waters 2487 Dual $\lambda$ Absorbance Detector (Waters, Milford, MA, USA) at room temperature. The results were quantitated with an external standard (Sigma-Aldrich, St. Louis, MO, USA).

\section{Statistical analysis}

The data are presented as the mean \pm SEM. Homogeneity of variances between the treatments was confirmed using Bartlett's test. All data were subjected to one-way analysis of variances (ANOVA) to test the main effect of treatment. When the main effect of the treatment was significant, the differences between the means were assessed using Duncan's multiple range tests. The level of significance was considered significant at $P<0.05$.

\section{Results}

Acute acetate treatment significantly inhibited feed intake within $5 \mathrm{~h}(P<0.05$; Figure 1A). Although the acetate treatment examined $4 \mathrm{~h}$ after acetate injection exhibited no effect on hypothalamic NPY, AGRP and CART mRNA levels in comparison with the control $(P>0.05)$, the acetate treatment significantly increased the $P O M C$ gene expression $(P<0.05$; Figure 1B). In comparison with the control group, the acetate injection did not affect the mRNA levels of hypothalamic GPR 41, acetyl-CoA carboxylase (ACC), fatty acid synthase $(F A S)$ or carnitine palmitoyltransferase-1 $(C P T 1)(P>0.05$; Figures $1 \mathrm{C}$ and $1 \mathrm{D})$; however, $G P R 43$ gene expression was significantly increased $(P<0.05$; Figure 1C).
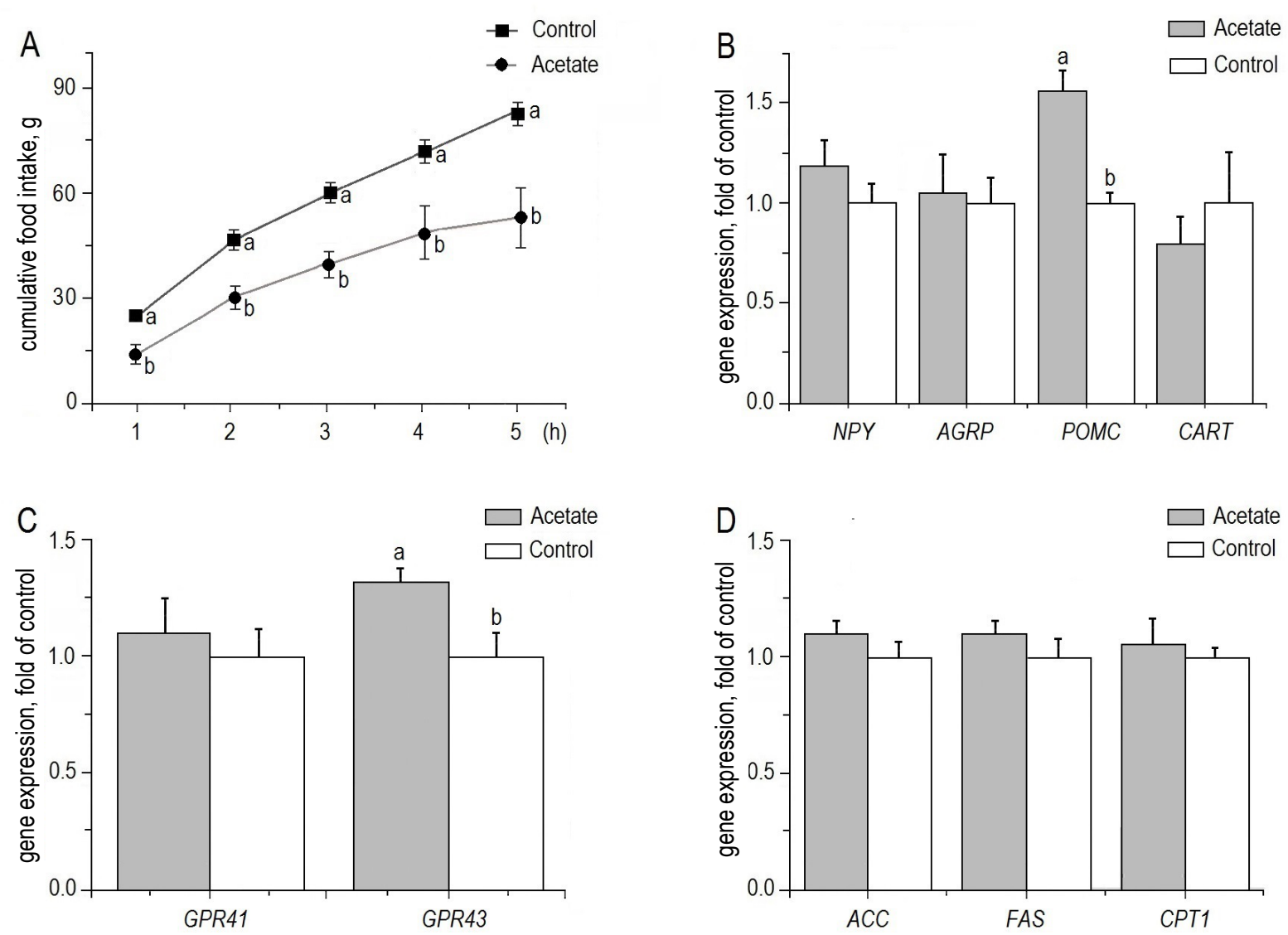

Figure 1. Effect of acetate treatment on $(A)$ food intake and mRNA levels of $(B)$ neuropeptide $Y(N P Y)$, agouti-related protein $(A G R P)$, proopiomelanocortin (POMC), cocaine-amphetamine-regulated transcript (CART), (C) G-protein-coupled receptor 41 (GPR41), G-protein-coupled receptor 43 (GPR43), (D) acetyl-CoA carboxylase alpha (ACC), fatty acid synthase (FAS) and carnitine palmitoyltransferase 1 (CPT1) in rabbits hypothalamus. Values are shown as the mean \pm SE (for food intake, $n=20$; for mRNA level, $n=8$ ); ab - points/bars with different letters are significantly different for each time point $(A)$ or each gene $(B-D)$ separately $(P<0.05)$ 

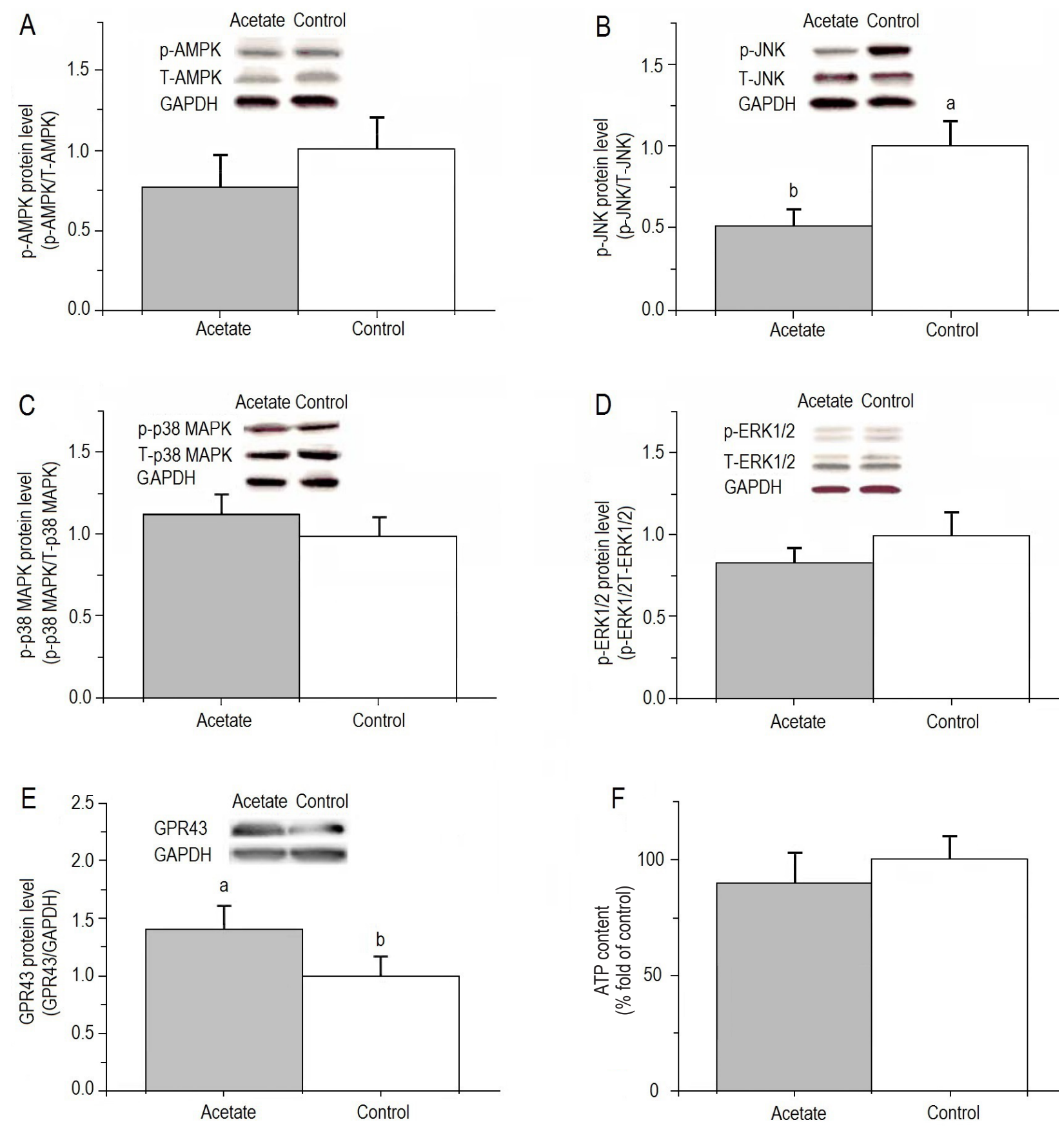

Figure 2. Effect of acetate treatment on hypothalamic (A) phosphorylated AMP-activated protein kinase (p-AMPK), (B) phosphorylated c-Jun $\mathrm{N}$-terminal kinases (p-JNK), (C) phosphorylated p38 mitogen-activated protein kinases (p-p38 MAPK), (D) phosphorylated extracellular signalregulated kinases $1 / 2$ (p-ERK1/2) and (E) G-protein-coupled receptor 43 (GPR43) protein levels and (F) ATP content in rabbits. Values are shown as the mean $\pm S E(n=6)$; ab - bars with different letters are significantly different $(P<0.05)$

No significant difference was observed in the protein levels of p-AMPK (Figure 2A), p-p38 MAPK (Figure 2C) or p-ERK (Figure 2D), and ATP content (Figure $2 \mathrm{~F}$ ) in the acetate group as compared with the control $(P>0.05)$. Conversely, the hypothalamic p-JNK protein level was significantly down-regulated after the acetate injection $(P<0.05$; Figure $2 \mathrm{~B})$. Besides, acetate treatment significantly increased hypothalamic GPR43 protein level $(P<0.05$; Figure $2 \mathrm{E})$.

\section{Discussion}

In the present study, the effect of acetate on appetite and the related pathways was examined. The results showed that an up-regulation of the $P O M C$ gene was responsible for the lower feed intake caused by acute acetate injection, and this process may be associated with membrane GPR43 and intracellular JNK signalling. 
Acetate induces anorexia by up-regulating hypothalamic POMC gene expression. In mice, acetate is an anorectic agent (Frost et al., 2014). In the present study, the gene expression of hypothalamic orexigenic and anorexigenic neuropeptides was evaluated. In the mammalian forebrain, $P O M C$ gene expression is limited to ARC neurons that project to areas that participate in energy homeostasis such as the paraventricular nucleus (PVN) (Kiss et al., 1984). In most studies, the POMC mRNA levels were measured to reflect a neuron activation (Schwartz et al., 1997; Challis et al., 2003). Being in line with previous experiments on rats (Frost et al., 2014), the present study demonstrated that acute acetate treatment increased hypothalamic $P O M C$ level in rabbits $4 \mathrm{~h}$ after acetate injection. The results suggest that the hypothalamic $P O M C$ gene is responsible for the anorexia in rabbits induced by acute acetate treatment. In our study, the expression of other appetite regulatory genes, such as $A G R P, C A R T$ and $N P Y$ was unaltered by acetate administration, suggesting that these appetite-regulating factors are not the main targets in acetate-induced anorexia when acetate is administered peripherally.

AMPK signalling is not involved in acetate-induced anorexia. As a hypothalamic energy and nutrient sensor, the blockade of AMPK signalling affects the expression of Pomc and Npy genes in rats (Ropelle et al., 2008). The effect of AMPK on appetite is regulated, at least in part, by inhibiting the activity of ACC. High hypothalamic concentrations of malonyl-CoA inhibit the activity of CPT1, leading to a decrease in the cellular levels of long-chain acyl-CoAs and an increase in feed intake (Andersson et al., 2004). Some recent studies suggested that acetate affected AMPK in a tissue-specific manner (Bergman, 1990; Hardie and Hawley, 2001; Li et al., 2014). Oxidative metabolism of acetate resulted in an increased ATP production, at the same time decreasing the AMP:ATP ratio, and thereby decreasing AMPK activity in rat hepatocytes and colonocytes (Bergman, 1990; Hardie and Hawley, 2001). However, hypothalamic p-AMPK protein levels as well as $A C C, F A S$ and $C P T 1$ mRNA levels were unaffected after acetate treatment in the present study, which is consistent with the study on porcine adipose tissue (Li et al., 2014). The obtained results imply that hypothalamic AMPK signalling may not be involved in the regulation of acetate-induced anorexia, because the hypothalamus is not a major tissue using SCFAs for ATP production.

JNK signalling is involved in acetate-induced anorexia. Nutritional status modifies the expression of hypothalamic neuropeptides through various sig- nalling molecules, i.e. extracellular MAPKs. Fasting can activate ERK in the ARC and p38 MAPK in the paraventricular nucleus (Morikawa et al., 2004). Furthermore, it is reported that melanocortin, corticotropin-releasing hormone, leptin and insulin can regulate appetite via hypothalamic MAPK signalling (Rahmouni et al., 2004; Refojo et al., 2005). The regulation of MAPK signalling is dependent on the specific regions and the state of energy balance (Morikawa et al., 2004). In the present study, the acute acetate treatment decreased the hypothalamic p-JNK protein level in the ARC of rabbits, suggesting that hypothalamic JNK signalling is associated with acetate-induced anorexia. Moreover, the increased $P O M C$ gene expression may be related to the JNK inhibition. Chai et al. (2009) found that the alteration of POMC receptor activation (melanocortin-4 receptor) could participate in the regulation of JNK activity in HEK293 cells. Although p38 MAPK and ERK signalling can regulate appetite in mammals (Morikawa et al., 2004; Kim et al., 2010), acute acetate treatment did not affect the level of phosphorylation of p38 MAPK and ERK proteins. These results suggest that $\mathrm{p} 38$ MAPK and ERK signalling may not be involved in the major signalling pathway in acetate-induced anorexia in rabbits.

Acetate induces anorexia in a GPR43-dependent manner. A recent study employing a 'reverse pharmacology' approach identified SCFAs (primarily acetate, propionate and butyrate) as ligands for the orphan receptors GPR41 and GPR43 (Nilsson et al., 2003). In the present study, the acetate treatment significantly increased hypothalamic GPR43 gene and protein expressions, which is in accordance with the results obtained in in vivo study on 3T3-L1 cells (Hong et al., 2005). The results may imply that acetate causes anorexia in a GPR43-dependent manner. In addition, it was stated that acetate exhibits a higher binding efficiency for GPR43 than GPR41 (Bindels et al., 2013), which may be the major reason why acetate did not affect hypothalamic GPR41 gene expression in the present experiment. Gpr43-knockout mice exhibited significantly higher feed intake and Pomc gene expression than wild type mice when fed a high-fat diet (Bjursell et al., 2011). Hence, there is a strong possibility that, in rabbits, acetate up-regulates POMC gene transcription via GPR43.

\section{Conclusions}

Acetate may induce anorexia via the up-regulation of hypothalamic pro-opiomelanocortin (POMC) gene expression, which may be associated with 
membrane G-protein-coupled receptor 43 (GPR43) and intracellular c-Jun N-terminal kinase (JNK) signalling.

\section{Acknowledgement}

This work was supported by the Postdoctoral Science Foundation of China (2015M580601), Modern Agro-industry Technology Research System (CARS-44-B-1), Funds of Shandong 'Double Tops' Program (2017), Youth Science and Technology Innovation Fund of Shandong Agricultural University (2015-2016), and Postdoctoral Science Foundation of Shandong Agricultural University (2015-2017).

\section{References}

Asakawa A., Inui A., Yuzuriha H., Nagata T., Kaga T., Ueno N., Fujino M.A., Kasuga M., 2001. Cocaine-amphetamine-regulated transcript influences energy metabolism, anxiety and gastric emptying in mice. Horm. Metab. Res. 33, 554-558, https://doi. org/10.1055/s-2001-17205

Andersson U., Filipsson K., Abbott C.R., Woods A., Smith K., Bloom S.R., Carling D., Small C.J., 2004. Small AMP-activated protein kinase plays a role in the control of food intake. J. Biol. Chem. 279, 12005-12008, https://doi.org/10.1074/jbc. C300557200

Bergman E.N., 1990. Energy contributions of volatile fatty acids from the gastrointestinal tract in various species. Physiol. Rev. 70, $567-590$

Bindels L.B., Dewulf E.M., Delzenne N.M., 2013. GPR43/FFA2: physiopathological relevance and therapeutic prospects. Trends Pharmacol. Sci. 34, 226-232, https://doi.org/10.1016/j. tips.2013.02.002

Bjursell M., Admyre T., Göransson M., Marley A.E., Smith D.M., Oscarsson J., Bohlooly Y.M., 2011. Improved glucose control and reduced body fat mass in free fatty acid receptor 2-deficient mice fed a high-fat diet. Am. J. Physiol.-Endocrinol. Metab. 300, E211-E220, https://doi.org/10.1152/ajpendo.00229.2010

Brady L.S., Smith M.A., Gold P.W., Herkenham M., 1990. Altered expression of hypothalamic neuropeptide mRNAs in foodrestricted and food-deprived rats. Neuroendocrinology 52 , 441-447, https://doi.org/10.1159/000125626

Chai B., Li J.-Y., Zhang W., Wang H., Mulholland M.W., 2009. Melanocortin-4 receptor activation inhibits c-Jun N-terminal kinase activity and promotes insulin signaling. Peptides 30, 10981104, https://doi.org/10.1016/j.peptides.2009.03.006

Challis B.G., Pinnock S.B., Coll A.P., Carter R.N., Dickson S.L., O'Rahilly S., 2003. Acute effects of PYY ${ }_{3-36}$ on food intake and hypothalamic neuropeptide expression in the mouse. Biochem. Biophys. Res. Commun. 311, 915-919, https://doi. org/10.1016/j.bbrc.2003.10.089

Chambers E.S., Morrison D.J., Frost G., 2015. Control of appetite and energy intake by SCFA: what are the potential underlying mechanisms? Proc. Nutr. Soc. 74, 328-336, https://doi. org/10.1017/S0029665114001657

Clark J.T., Kalra P.S., Crowley W.R., Kalra S.P., 1984. Neuropeptide Y and human pancreatic polypeptide stimulate feeding behavior in rats. Endocrinology 155, 427-429, https://doi.org/10.1210/ endo-115-1-427
Cobb M.H., 1999. MAP kinase pathways. Prog. Biophys. Mol. Bio. 71 479-500, https://doi.org/10.1016/S0079-6107(98)00056-X

de Blas C., Mateos G.G., 2010. Feed formulation. In: C. de Blas., J. Wiseman (Editors). Nutrition of the Rabbit. $2^{\text {nd }}$ Edition. CABI, Wallingfold (UK), pp. 222-232

Frost G., Sleeth M.L., Sahuri-Arisoylu M. et al., 2014. The short-chain fatty acid acetate reduces appetite via a central homeostatic mechanism. Nat. Commun. 5, 3611, https://doi.org/10.1038/ ncomms4611

Hardie D.G., Hawley S.A., 2001. AMP-activated protein kinase: the energy charge hypothesis revisited. Bioessays 23, 1112-1119, https://doi.org/10.1002/bies.10009

Hong Y.-H., Nishimura Y., Hishikawa D. et al., 2005. Acetate and propionate short chain fatty acids stimulate adipogenesis via GPCR43. Endocrinology 146, 5092-5099, https://doi. org/10.1210/en.2005-0545

Hu G.-X., Chen G.-R., Xu H., Ge R.-S., Lin J., 2010. Activation of the AMP activated protein kinase by short-chain fatty acids is the main mechanism underlying the beneficial effect of a high fiber diet on the metabolic syndrome. Med. Hypotheses 74, 123-126, https://doi.org/10.1016/j.mehy.2009.07.022

Kim E.-K., Miller I., Aja S., Landree L.E., Pinn M., McFadden J., Kuhajda F.P., Moran T.H., Ronnett G.V., 2004. C75, a fatty acid synthase inhibitor, reduces food intake via hypothalamic AMPactivated protein kinase. J. Biol. Chem. 279, 19970-19976, https://doi.org/10.1074/jbc.M402165200

Kim G.L., Dhillon S.S., Belsham D.D., 2010. Kisspeptin directly regulates neuropeptide $Y$ synthesis and secretion via the ERK1/2 and p38 mitogen-activated protein kinase signaling pathways in NPY-secreting hypothalamic neurons. Endocrinology 151, 5038-5047, https://doi.org/10.1210/en.2010-0521

Kimura I., Inoue D., Hirano K., Tsujimoto G., 2014. The SCFA receptor GPR43 and energy metabolism. Front. Endocrinol. 5, 85, https://doi.org/10.3389/fendo.2014.00085

Kiss J.Z., Cassell M.D., Palkovits M., 1984. Analysis of the ACTH/ßEnd/a-MSH-immunoreactive afferent input to the hypothalamic paraventricular nucleus of rat. Brain Res. 324, 91-99, https://doi.org/10.1016/0006-8993(84)90625-5

Kohno D., Sone H., Tanaka S., Kurita H., Gantulga D., Yada T., 2011. AMP-activated protein kinase activates neuropeptide $Y$ neurons in the hypothalamic arcuate nucleus to increase food intake in rats. Neurosci. Lett. 499, 194-198, https://doi. org/10.1016/j.neulet.2011.05.060

Li G., Yao W., Jiang H., 2014. Short-chain fatty acids enhance adipocyte differentiation in the stromal vascular fraction of porcine adipose tissue. J. Nutr. 144, 1887-1895, https://doi.org/10.3945/ jn.114.198531

Liu L., Song Z., Jiao H., Lin H., 2014. Glucocorticoids increase NPY gene expression via hypothalamic AMPK signaling in broiler chicks. Endocrinology 155, 2190-2198, https://doi. org/10.1210/en.2013-1632

Livak K.J., Schmittgen T.D., 2001. Analysis of relative gene expression data using real-time quantitative PCR and the 2(-Delta Delta $\mathrm{C}_{\mathrm{T}}$ ) method. Methods 25, 402-408, https://doi.org/10.1006/ meth.2001.1262

Mano-Otagiri A., Nemoto T., Sekino A., Yamauchi N., Shuto Y., Sugihara H., Oikawa S., Shibasaki T., 2006. Growth hormonereleasing hormone (GHRH) neurons in the arcuate nucleus (Arc) of the hypothalamus are decreased in transgenic rats whose expression of ghrelin receptor is attenuated: evidence that ghrelin receptor is involved in the up-regulation of GHRH expression in the Arc. Endocrinology 147, 4093-4103, https:// doi.org/10.1210/en.2005-1619 
Mizuno T.M., Makimura H., Silverstein J., Roberts J.L., Lopingco T., Mobbs C.V., 1999. Fasting regulates hypothalamic neuropeptide $\mathrm{Y}$, agouti-related peptide, and proopiomelanocortin in diabetic mice independent of changes in leptin or insulin. Endocrinology 140, 4551-4557, https://doi.org/10.1210/ endo.140.10.6966

Morikawa Y., Ueyama E., Senba E., 2004. Fasting-induced activation of mitogen-activated protein kinases (ERK/p38) in the mouse hypothalamus. J. Neuroendocrinol. 16, 105-112, https://doi. org/10.1111/j.0953-8194.2004.01135.x

Nilsson N.E., Kotarsky K., Owman C., Olde B., 2003. Identification of a free fatty acid receptor, FFA $R$, expressed on leukocytes and activated by short-chain fatty acids. Biochem. Biophys. Res. Commun. 303, 1047-1052, https://doi.org/10.1016/ S0006-291X(03)00488-1

Prior L.J., Eikelis N., Armitage J.A., Davern P.J., Burke S.L., Montani J.P., Barzel B., Head G.A., 2010. Exposure to a high-fat diet alters leptin sensitivity and elevates renal sympathetic nerve activity and arterial pressure in rabbits. Hypertension 55, 862-868, https://doi.org/10.1161/HYPERTENSIONAHA.109.141119

Rabbani G.H., Albert M.J., Rahman H., Chowdhury A.K., 1999. Shortchain fatty acids inhibit fluid and electrolyte loss induced by cholera toxin in proximal colon of rabbit in vivo. Dig. Dis. Sci. 44, 1547-1553, https://doi.org/10.1023/A:1026650624193

Rahmouni K., Morgan D.A., Morgan G.M., Liu X., Sigmund C.D., Mark A.L., Haynes W.G., 2004. Hypothalamic PI3K and MAPK differentially mediate regional sympathetic activation to insulin. J. Clin. Invest. 114, 652-658, https://doi.org/10.1172/ $\mathrm{JCl} 21737$

Refojo D., Echenique C., Müller M.B., Reul J.M.H.M., Deussing J.M., Wurst W., Sillaber I., Paez-Pereda M., Holsboer F., Arzt E., 2005. Corticotropin-releasing hormone activates ERK1/2 MAPK in specific brain areas. Proc. Natl. Acad. Sci. USA 102, 6183-6188, https://doi.org/10.1073/pnas.0502070102

Ropelle E.R., Pauli J.R., Fernandes M.F.A. et al., 2008. A central role for neuronal AMP-activated protein kinase (AMPK) and mammalian target of rapamycin (mTOR) in high-protein diet-induced weight loss. Diabetes 57, 594-605, https://doi. org/10.2337/db07-0573
Rossi M., Kim M.S., Morgan D.G.A. et al., 1998. A C-terminal fragment of agouti-related protein increases feeding and antagonizes the effect of alpha-melanocyte stimulating hormone in vivo. Endocrinology 139, 4428-4431, https://doi.org/10.1210/ endo.139.10.6332

Rumberger J.M., Arch J.R.S., Green A., 2014. Butyrate and other short-chain fatty acids increase the rate of lipolysis in 3T3-L1 adipocytes. PeerJ. 2, e611, https://doi.org/10.7717/peerj.611

Savontaus E., Conwell I.M., Wardlaw S.L., 2002. Effects of adrenalectomy on AGRP, POMC, NPY and CART gene expression in the basal hypothalamus of fed and fasted rats. Brain Res. 958, 130-138, https://doi.org/10.1016/S0006-8993(02)03674-0

Schaeffer H.J., Weber M.J., 1999. Mitogen-activated protein kinases: specific messages from ubiquitous messengers. Mol. Cell. Biol. 19, 2435-2444, https://doi.org/10.1128/MCB.19.4.2435

Schwartz M.W., Seeley R.J., Woods S.C., Weigle D.S., Campfield L.A., Burn P., Baskin D.G., 1997. Leptin increases hypothalamic pro-opiomelanocortin mRNA expression in the rostral arcuate nucleus. Diabetes 46, 2119-2123, https://doi.org/10.2337/ diab.46.12.2119

Smolenski R.T., Yacoub M.H., 1993. Liquid chromatographic evaluation of purine production in the donor human heart during transplantation. Biomed. Chromatogr. 7, 189-195, https://doi. org/10.1002/bmc.1130070404

Tritos N.A., Vicent D., Gillette J., Ludwig D.S., Flier E.S., MaratosFlier E., 1998. Functional interactions between melaninconcentrating hormone, neuropeptide $\mathrm{Y}$, and anorectic neuropeptides in the rat hypothalamus. Diabetes 47, 1687-1692, https://doi.org/10.2337/diabetes.47.11.1687

Tsaousidou E., Paeger L., Belgardt B.F. et al., 2014. Distinct roles for JNK and IKK activation in agouti-related peptide neurons in the development of obesity and insulin resistance. Cell Rep. 9, 1495-1506, https://doi.org/10.1016/j.celrep.2014.10.045 